B. Yu. Sobko, orcid.org/0000-0002-6872-8458,

O. V. Lozhnikov, orcid.org/0000-0003-1231-0295, M. O. Chebanov, orcid.org/0000-0002-6681-2701, V.A. Kardash, orcid.org/0000-0002-7947-7789
Dnipro University of Technology, Dnipro, Ukraine, e-mail: sobko.boris.nmu@gmail.com

\title{
SUBSTANTIATING RATIONAL SCHEDULE TO LOAD TRUCKS USING DRAGLINES WHILE MINING A PIT OF MOTRONIVSKYI MPP
}

Purpose. To substantiate a rational schedule for the combined dragline-truck operation taking into consideration a coefficient of mining in the context of the pit.

Methodology. Mathematical and graphical modeling was involved while determining a coefficient of mining concentration in the pit as well as feasibility analysis to select a rational procedure scheme for dragline operation.

Findings. Recommendations for the selection of rational dragline operation, while truck loading in the context of Motronivsko-Annivskyi pit, have been developed taking into consideration mining concentration degree in the pit. It has been determined that bottom dragline unloading into a truck, located in the central part of bench mining width, as well as the dragline position at 0.5 A distance from the bench crest, is the most efficient plan of action for the conditions. Technological scheme to develop Motronivsko-Annivskyi pit has been proposed.

Originality. Dependence of the mining concentration in the pit upon the parameters of development system elements according to different technological schemes has been derived. The dependence helps estimate development cost for overburden rocks using draglines with direct unloading into trucks.

Practical value. Technological schemes for the combined dragline - dump truck operation have been developed. Their use makes it possible to cut the prime cost of overburden activities. Implementation of the proposed solutions helps cut stripping cost by UAH 79.65 million a year if annual overburden volume is $Q_{\text {rozkryvu }}-Q_{\text {stripping }}=13.5$ million $\mathrm{m}^{3} /$ year.

Keywords: dragline, dump truck, excavator productivity, coefficient of mining concentration, stripping cost

Introduction. Ukraine is rich in primary and placer titanium ore deposits. For many years, placer deposits have been developed in Ukraine, where minerals occur at a shallow depth; hence, they did not require sizable investment and complex technological solutions for extraction. However, the demand for titanium raw materials grows, and the reserves of deposits, being mined, are of deeper ore occurrence in addition to complex hydrogeological conditions. MotronivskoAnnivskyi site of Malyshevskyi titanium-zirconium deposit is one of them $[1,2]$.

The deposit has a complex hydrogeological structure; the ore is represented by fine-grained drift sand with low water yield. This property of ore sand prevented from using the known methods of dewatering and rock draining [3]. Therefore, ore layer is developed using hydromechanization with suction dredgers. However, the development method remains above ore bench in a water-saturated state with poor stability $[4,5]$. Hence, it has been decided to use draglines with direct unloading into a truck for the development of overburden [6]. The solution depends upon low specific dragline pressure on the soil $[7,8]$.

Generally, the majority of scientific papers, that analyze the methods with a dragline, concern application area as well as substantiation of technological schemes in terms of dragline mining system.

Paper [9] considers fully parameters of dragline excavator ESh (ЭШ) + truck complex operation. Optimum values of a bench height and bench face width for the conditions of Yeristovskyi itabirite deposit have been defined in terms of different positions of a truck. However, dragline efficiency did not become the key optimality criterion. Minimum capacity losses show only the availability of optimum values of the bench face width parameters. Nevertheless, it does not mean that maximum actual efficiency will be achieved in terms of the parameters. Moreover, analysis of a rotation angle in the context of a dragline with lower unloading and truck position at a dragline

(c) Sobko B. Yu., Lozhnikov O. V., Chebanov M. O., Kardash V.A., 2021 position level is impartial. In addition, the dragline position was assumed near a bench crest (as it is done in terms of nonhaulage development system) which increased its unloading rotation angle.

Technological schemes of dragline excavators operation in combination with trucks are not sufficiently studied; they have different optimal technological parameters of the excavator face when its maximum productivity is achieved [10]. Thus, substantiation of rational technological schemes of dragline operation in the context of Motronivskyi MPP is an urgent scientific task to cut stripping cost.

Determining parameters of development system elements in terms of different stripping technological schemes. The use of dragline systems for direct truck loading has many disadvantages. The reduced excavator efficiency compared to nonhaulage technique is the key one [11, 12].

In this regard, studies on the technological schemes of dragline operation with truck loading have been carried out [13, 14]; optimum bench face parameters have been determined.

The research makes it possible to support the idea that there are 4 schemes with the maximum dragline efficiency (Fig. 1):

- scheme 1: a dragline is located at a 0.5 A distance from a bench crest; unloading is performed into a truck located at a level being comparable with an excavator position which is at the level of the excavator near the protection embankment (Fig. 1,a);

- scheme 2: a dragline is located at a safe distance $B_{1}$ from a bench crest; unloading is performed into a truck located at an excavator level near the protection embankment (Fig. 1,b);

- scheme 3: a dragline is at a 0.5 A distance from a bench crest; unloading is performed into a truck located lower compared with the dragline position being in the central part of the bench width (Fig. 1,c);

- scheme 4: a dragline is at a safe distance $B_{1}$ from a bench crest; unloading is performed into a truck located lower compared with the dragline position being in the central part of the bench width (Fig. 1, d). 


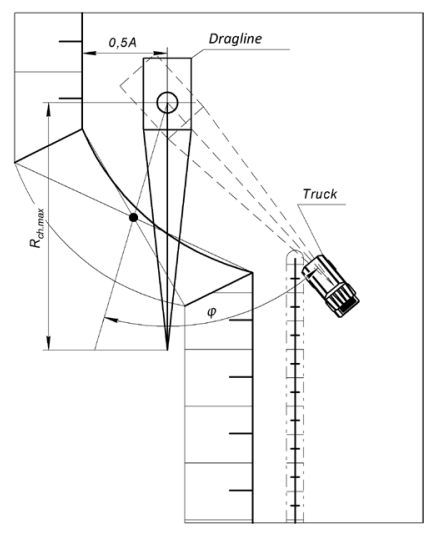

$a$

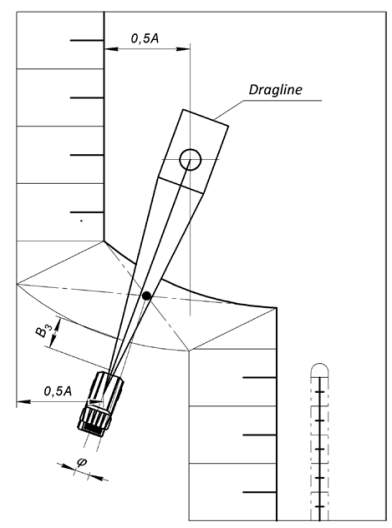

$c$

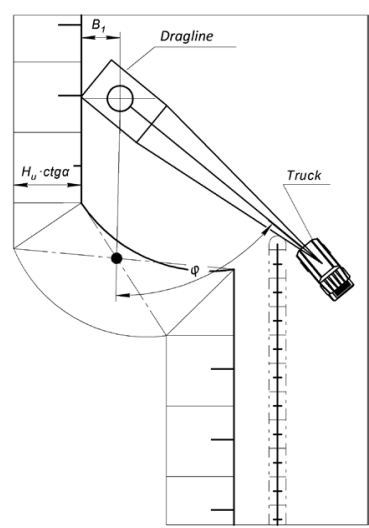

$b$

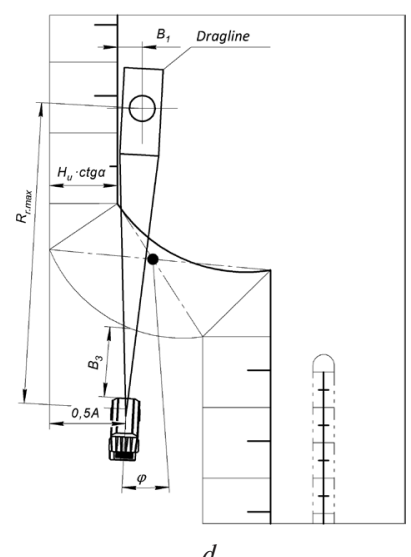

$d$
Fig. 1. Technological schemes of dragline-truck system operation: a-scheme 1; $b$-scheme 2; $c$-scheme 3; $d$-scheme 4

In terms of Motronivsko-Annivskyi pit, scheme 1 with $H=$ $=10 \mathrm{~m}$ bench height and $A=30 \mathrm{~m}$ bench width is used for the stripping; denote it as a scheme 5 for further calculations.

The considered schemes are cyclical; they have not any inextricable connection with the dumping operations. The abovementioned makes it possible to develop a working bench with some independence from the formation of the internal dump board and vary parameters of the mining benches $[15,16]$.

Expansion of the mining benches when a highwall is extracted results in the decreased mining concentration rate in the pit [2]. In turn, this leads to the increase in stripping volume owing to the pit enlargement [17, 18]. Consequently, selection of rational technological scheme of dragline-truck system operation should involve determination of inter-ramp angle as well as a degree of mining concentration for each of the four schemes and their comparison.
$H=10 \mathrm{~m}$ is the rational bench height for the proposed schemes. Since average overburden thickness of Motronivskyi placer is $m=40 \mathrm{~m}$, it is suggested to perform overburden operations by means of four $10 \mathrm{~m}$ levels.

In the context of the current scheme, $h=10 \mathrm{~m}$ ore bench is flooded; it is developed using dredgers. We assume the mining technique for the four proposed stripping operation schemes.

However, when using the mining technology, the ore bench is flooded, preventing from the dump truck position on its roof. Therefore, when using schemes 3 and 4 for stripping, the overburden ledge will be developed according to scheme 1 .

To calculate the slope of the working side of the pit, we use the following formula

$$
\varphi=\operatorname{arctg} \frac{\sum_{i=1}^{n_{p}} H_{u i}+h}{\sum_{i=1}^{n_{b}} h_{i} \operatorname{ctg} \gamma_{i}+\sum_{i=1}^{n_{p}} H_{u_{i}} \operatorname{ctg} \alpha_{i}+\sum_{i=1}^{n_{n}} S h_{i}},
$$

where $n$ is the number of development ledges; $i$ is the serial number of the ledge; $H_{u}$ is height of the mining ledges, $\mathrm{m} ; \gamma$ is slope angle of the production ledge, deg.; $\gamma=44$ deg.; $S h$ is working area width of the ledge.

The work platforms width is determined by the formula

$$
S h_{p}=A+C+P+T+z,
$$

where $C$ is distance from the lower edge of the ledge to the transportation line; $T$ is width of the transportation line, $\mathrm{m}$ ( $T=11 \mathrm{~m}$ according to SNiP 2.05.07-91); $P$ is width of the line for additional equipment and power supply, $\mathrm{m} ; z$ is width of safety berm, $\mathrm{m}$.

The resulting angle of the pit working side inclination for each scheme has been calculated; Table 1 demonstrates the outcomes.

Analysis of Table 1 shows that the largest angle of the working side of the pit, being $\varphi=12.8^{\circ}$, is achieved by using the technological scheme with lower unloading (scheme 3 ), and the smallest angle of the working side of open the pit $\varphi=11.7^{\circ}$ with the scheme with unloading at the installation level (scheme 2).

In terms of scheme 3, larger angle of the working side of the pit depends upon the smaller working bench width [19].

For more detailed study and selection of the technological scheme of the dragline excavator, we calculate $\mathrm{Kg}$ being a degree of mining operations concentration. It is determined by the ratio between minimum allowable area of the pit and the actual one [2].

The indicator of the degree of mining operations concentration in the pit is determined by the formula

$$
K g=\frac{S_{d o p}}{S_{f}},
$$

\begin{tabular}{|c|c|c|c|c|c|c|c|c|c|c|c|c|c|c|c|c|c|c|c|c|}
\hline \multirow{3}{*}{$\begin{array}{l}\text { Development system } \\
\text { elements }\end{array}$} & \multicolumn{5}{|c|}{ Scheme 1} & \multicolumn{5}{|c|}{ Scheme 2} & \multicolumn{5}{|c|}{ Scheme 3} & \multicolumn{5}{|c|}{ Scheme 4} \\
\hline & \multicolumn{4}{|c|}{ Overburden ledges } & \multirow{2}{*}{ k. k. } & \multicolumn{4}{|c|}{ Overburden ledges } & \multirow{2}{*}{ k. k. } & \multicolumn{4}{|c|}{ Overburden ledges } & \multirow{2}{*}{ k. k. } & \multicolumn{4}{|c|}{ Overburden ledges } & \multirow{2}{*}{ k. k. } \\
\hline & 1 & 2 & 3 & 4 & & 1 & 2 & 3 & 4 & & 1 & 2 & 3 & 4 & & 1 & 2 & 3 & 4 & \\
\hline Bench height, $\mathrm{m}$ & 10 & 10 & 10 & 10 & 10 & 10 & 10 & 10 & 10 & 10 & 10 & 10 & 10 & 10 & 10 & 10 & 10 & 10 & 10 & 10 \\
\hline Working bench width, $\mathrm{m}$ & 24 & 24 & 24 & 24 & 30 & 28 & 28 & 28 & 28 & 30 & 22 & 22 & 22 & 24 & 30 & 24 & 24 & 24 & 28 & 30 \\
\hline Working slope angle, deg & 40 & 40 & 40 & 40 & 27 & 40 & 40 & 40 & 40 & 27 & 40 & 40 & 40 & 40 & 27 & 40 & 40 & 40 & 40 & 27 \\
\hline Stable slope angle, deg & 32 & 32 & 32 & 32 & 44 & 32 & 32 & 32 & 32 & 44 & 32 & 32 & 32 & 32 & 44 & 32 & 32 & 32 & 32 & 44 \\
\hline Width of the work site, $\mathrm{m}$ & 42 & 42 & 42 & 42 & 70 & 46 & 46 & 46 & 46 & 70 & 40 & 40 & 40 & 42 & 70 & 42 & 42 & 42 & 46 & 70 \\
\hline $\begin{array}{l}\text { Overall angle of the } \\
\text { working side of the pit, deg }\end{array}$ & \multicolumn{5}{|c|}{12.5} & \multicolumn{5}{|c|}{11.7} & \multicolumn{5}{|c|}{12.8} & \multicolumn{5}{|c|}{12.3} \\
\hline
\end{tabular}

Table 1

Parameters of development system elements when using different schemes of overburden works 
where $S_{d o p}$ is minimum allowable area of the pit under the rock mass stability conditions, ha; $S_{f}$ is actual area of the pit in terms of the applied development system, ha

$$
S_{f}=L_{r . z .} \cdot\left(\left(H_{r}+h\right) \cdot\left(\operatorname{ctg} \varphi+\operatorname{ctg} \beta_{v}\right)+b\right),
$$

where $L_{r . z .}$ is surface length of the working zone of the pit, m; $\beta_{v}$ is resulting slope angle of an internal dump, deg. (being $\beta_{v}=$ $=15^{\circ}$ for the existing dumping method); $b$ is distance between the toe of mining bench and the dump, $\mathrm{m}$.

The minimum allowable area of the pit is calculated by the formula

$$
S_{\text {dop }}=L_{d o p} \cdot\left(\left(H_{r}+h\right) \cdot\left(\operatorname{ctg} \varphi+\operatorname{ctg} \beta_{E}\right)+b\right),
$$

where $L_{d o p}$ is minimum allowable surface length of the working area of the pit, $\mathrm{m} ; \beta_{E}$ is stable angle of internal dump inclination, deg; $\varphi_{E}$ is stable angle of the working side of the pit, deg.

$\beta_{E}=18.4^{\circ}$ and $\varphi_{E}=31.4^{\circ}$ in the context of MotronivskoAnnivskyi placer development [4].

The actual pit working area and the value of the indicator of the mining operations concentration degree were calculated for each of the four proposed schemes. Diagram in Fig. 2 demonstrates the calculation results.

While analysing the calculation results of the concentration of mining operations in the pit (Fig. 2), we can say that a scheme with lower unloading and dragline position at a distance of $0.5 \mathrm{~A}$ from the upper ledge (scheme 3 ) is the most effective technological procedure when a dragline is combined with trucks [20, 21]. That depends upon the fact that the highest mining operation concentration in the pit is $K_{g}=0.64$ indicating the minimum values of the working area of the pit compared with other schemes.

Resulting from the research as well as calculations of the degree of concentration of mining operations in the pit, we select the scheme of dragline with lower unloading in a dump truck, located in the centre the bench width (scheme 3) to work in Motronivsko-Annivskyi pit.

To calculate stripping cost, it is necessary to determine the required amount of mining and transport equipment to ensure the annual production of overburden as Apl.year $=13.5$ million $\mathrm{m}^{3} /$ year.

Calculate the amount of mining equipment for each of the proposed schemes.

Dragline shift performance is determined by the formula

$$
Q_{v . z m}=Q_{v . g o d} \cdot T_{z m} \cdot k_{t . v} \cdot k_{n . p .} \cdot k_{r o z} \cdot k_{v y k},
$$

where $T_{z m}$ is shift duration, hours, $T_{z m}=12$ hours; $k_{t . v}$ is coefficient of extraction technology, $k_{t . v}=0.83 ; k_{n . p .}$ is coefficient that takes into account the accumulation of rock in the complex hydrogeological conditions of Motronivsko-Annivskyi pit, $k_{n . p .}=0.9 ; k_{r o z}$ is unloading factor, which takes into account the rock shedding when unloading the dragline in the dump

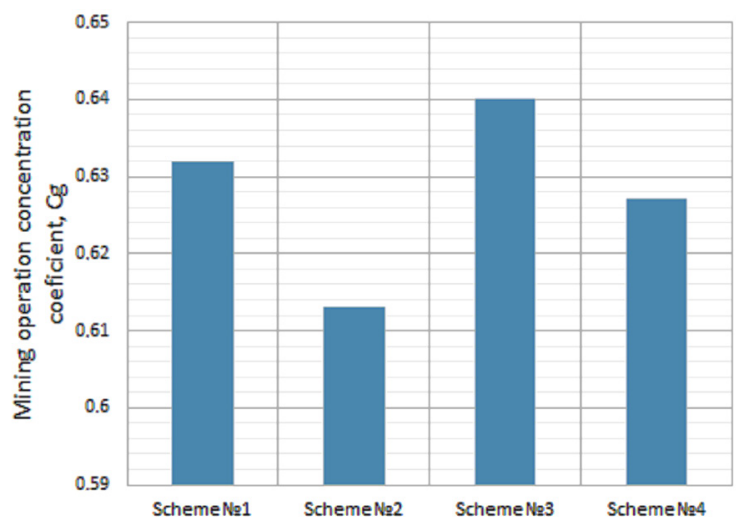

Fig. 2. Indicator of mining operations concentration in the pit for each of the proposed working schemes of a dragline excavator ESh-10/50 in combination with trucks truck due to the design features of the bucket (reverse bucket), $k_{\text {ros }}=0.8 ; k_{v y k}$ is coefficient of excavator operation in time under transport conditions which takes into account the time for exchange of dump trucks. We assume it as $k_{v y k}=0.7$.

Annual productivity of dragline excavators ESh 10/50 (EШ-10/50) is calculated according to the formula

$$
Q_{\text {e.rik }}=Q_{\text {e.zm }} \cdot n_{z m} \cdot N_{D},
$$

where $n_{z m}$ is the number of complete work shifts per day, $n_{z m}=2$ shifts; $N_{D}$ is the number of working days in the year, $N_{D}=260$

Determine the required number of draglines to perform the planned stripping operations if $A_{\text {pl.year }}=13.5$ million m $3 /$ year.

$$
N_{D}=\frac{A_{p l}}{Q_{e . r i k}} .
$$

Determine the required number of Cat-773E trucks for the excavator.

The duration of the dump truck loading cycle with ore sand is calculated by the formula, $\mathrm{s}$

$$
t_{c . n .}=\frac{V}{E} \cdot \frac{t_{c}}{60},
$$

where $V$ is volume of the truck body, $V=26.6 \mathrm{~m}^{3}$. The cycle duration is selected using timing and calculating values of turn duration for each of the schemes involving optimal parameters of the bench face.

Duration of the dump track trip is (s)

$$
t_{r}=t_{c . n .}+\frac{2 L_{p} \cdot 60}{v_{a v}}+t_{r o z}
$$

where $L_{p}$ is average rock mass transportation distance to the dump, $\mathrm{km}$; it is $L_{p}=2 \mathrm{~km}$ for schemes with unloading at the level of standing, $L_{p}=2.1 \mathrm{~km}$ for schemes with unloading below the level of standing; $v_{a v}$ is dump truck speed $v_{a v}=25 \mathrm{~km} / \mathrm{h}$; $t_{r o z}$ is duration of unloading of the dump truck, $t_{r o z}=1 \mathrm{~min}$.

The shift performance per shift of one truck will be

$$
Q_{a . z m}=\frac{60 \cdot T_{s m}}{t_{r}} \cdot V \cdot k_{n . a .} \cdot k_{s m . v},
$$

where $k_{\text {n.a. }}$ is coefficient of filling the dump truck body, $k_{\text {n.a. }}=1$; $k_{s m . v}$ is coefficient taking into consideration a truck during the shift being $k_{\text {sm.v. }}=0.85$.

The required number of trucks for one excavator is calculated by the formula

$$
N_{a}=\frac{Q_{e . z m}}{Q_{a . z m}}
$$

The total number of dump trucks is calculated by the formula

$$
N_{a . z a d}=N_{a} \cdot N_{D} .
$$

Table 2 demonstrates the calculation results.

To select the required technology, we calculate the cost of stripping $1 \mathrm{~m}^{3}$ of rock mass for the proposed options.

The production programme of the sections of the mining enterprise is based on the selected technology of stripping, provision of mining equipment and mode of operation of the enterprise. The number of working days in terms of a breaking mode with a six-day working week is 305 . The number of shifts per day is 2, 12 hours each.

The cost of $1 \mathrm{~m}^{3}$ of stripping is calculated on the basis of the above production costs for wages, auxiliary materials, fuel, depreciation by summing them. Calculation of the cost of stripping is given in Table 3.

$$
C_{1,2}=\frac{\sum Z}{Q_{r i k}}
$$



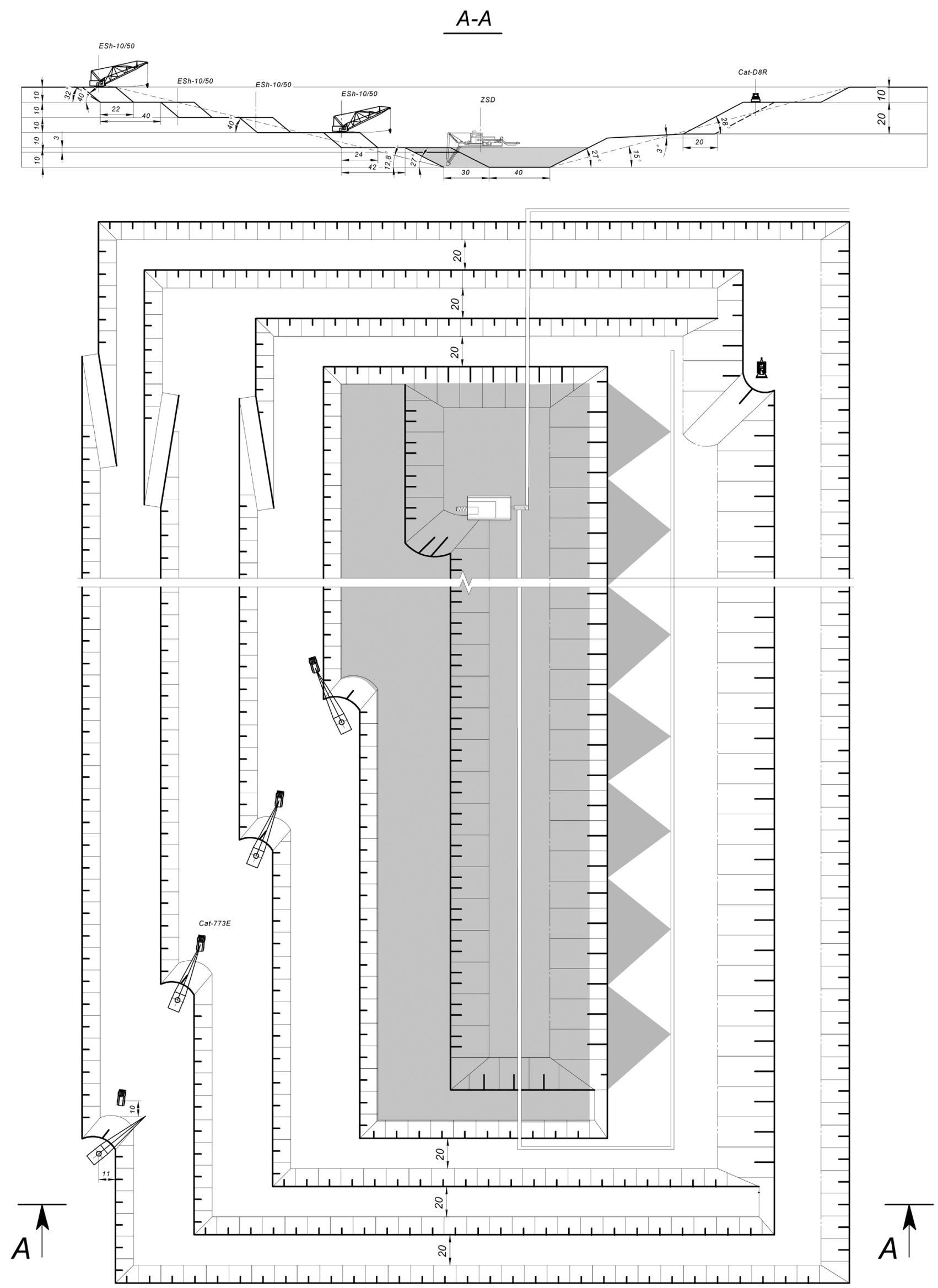

Fig. 3. Technological scheme to develop Motronivsko-Annivskyi placer 
Conclusions. The most effective technological schemes of

Parameters of the schemes of dragline operation combined with trucks in terms of Motronivsko-Annivskyi pit

\begin{tabular}{|l|c|c|c|c|c|}
\hline \multirow{2}{*}{\multicolumn{1}{|c|}{ Parameters }} & \multicolumn{5}{|c|}{ Schemes } \\
\cline { 2 - 7 } & 1 & 2 & 3 & 4 & 5 \\
\hline Bench height, $\mathrm{m}$ & 10 & 10 & 10 & 10 & 10 \\
\hline Working bench width, $\mathrm{m}$ & 24 & 28 & 22 & 24 & 30 \\
\hline $\begin{array}{l}\text { Duration of the loading } \\
\text { cycle, min }\end{array}$ & 1.8 & 1.8 & 1.5 & 1.5 & 1.8 \\
\hline $\begin{array}{l}\text { Annual productivity of the } \\
\text { excavator, thousand } \mathrm{m}^{3} / \mathrm{year}\end{array}$ & 1574 & 1585 & 1792 & 1791 & 1565 \\
\hline $\begin{array}{l}\text { Number of dragline } \\
\text { excavators ESh } 10 / 50\end{array}$ & 9 & 9 & 8 & 8 & 9 \\
\hline Number of Cat-773E & 27 & 27 & 24 & 24 & 27 \\
\hline
\end{tabular}

Table 3

Calculation of the cost of stripping by $1 \mathrm{~m}^{3}$

\begin{tabular}{|c|c|c|c|c|c|}
\hline \multirow[t]{2}{*}{ Elements of cost } & \multicolumn{5}{|c|}{$\begin{array}{l}\text { Costs for the annual volume of stripping } \\
\left(13.5 \text { million } \mathrm{m}^{3}\right) \text {, UAH million using the } \\
\text { schemes }\end{array}$} \\
\hline & 1 & 2 & 3 & 4 & 5 \\
\hline Basic salary & 10.5 & 12.2 & 10.8 & 10.8 & 12.2 \\
\hline $\begin{array}{l}\text { Additional salary } \\
\text { ( } 9 \% \text { of the basic) }\end{array}$ & 0.9 & 1.1 & 0.97 & 0.97 & 1.1 \\
\hline Wages together & 11.4 & 13.3 & 11.7 & 11.7 & 13.3 \\
\hline $\begin{array}{l}\text { Salary accruals } \\
\text { (22\% of wages) }\end{array}$ & 2.5 & 2.9 & 2.5 & 2.5 & 2.9 \\
\hline $\begin{array}{l}\text { Basic and auxiliary } \\
\text { materials }\end{array}$ & 7.9 & 7.9 & 7.8 & 7.8 & 7.89 \\
\hline Fuel & 277.9 & 277.9 & 247.0 & 247.0 & 277.9 \\
\hline Depreciation & 216.1 & 216.1 & 192.1 & 192.1 & 216.1 \\
\hline Electricity & 177.8 & 177.8 & 157.3 & 157.3 & 180.1 \\
\hline Total & 693.8 & 696.1 & 618.8 & 618.8 & 698.4 \\
\hline $\begin{array}{l}\text { Cost of } 1 \mathrm{~m}^{3} \text { of } \\
\text { stripping, UAH }\end{array}$ & 51.40 & 51.57 & 45.84 & 45.84 & 51.74 \\
\hline
\end{tabular}

Results. As it is understood from Table 3 data, the main share of costs for each of the schemes is covered by the costs of fuel, electricity, and depreciation. It is also seen that the minimum cost of stripping will be when using schemes with lower unloading depending upon the greater productivity of the dragline, and hence the smaller amount of mining equipment. Thus, schemes 3 and 4 are the least expensive.

The cost of production under the existing technological scheme of operation of a dragline excavator ESh-10/50 (ЕШ10/50) in a complex with trucks in Motronivsko-Annivskyi pit is UAH 51.74 per $\mathrm{m}^{3}$. Use of the scheme with the lower unloading, and the optimal parameters of the face will reduce stripping cost of $1 \mathrm{~m}^{3}$ of rock mass by UAH 5.9 and reduce the total stripping cost

UAH $P=(51.75-45.84) \cdot 13.5=79.65$ million a year.

Resulting from the research as well as calculations of the degree of concentration of mining operations in the pit, we select the scheme of dragline with lower unloading in a dump truck, located in the centre the bench width (scheme 3) to work in Motronivsko-Annivskyi pit.

The calculations have helped us elaborate a technological scheme to develop the pit of Motronivskyi MPP (Fig. 3). dragline excavator operation in combination with dump truck according to technical and economic calculation have been determined. The schemes are those ones with lower unloading and position of a dump truck in the centre of the working bench width being schemes 3 and 4 . The cost of $1 \mathrm{~m}^{3}$ of stripping operations with the use of these schemes amounts to $C=$ $=$ UAH 45.84 per $\mathrm{m}^{3}$, which is by $3 \%$ lower than the current one. Application of the technological scheme with lower unloading helps reduce the stripping costs by UAH 79.65 million a year with the annual stripping productivity of the pit being $Q_{\text {stripping. }}=13.5$ million $\mathrm{m}^{3} /$ year.

The developed recommendations on the selection of rational schemes of dragline excavators with truck loading for Motronivsko-Annivskyi pit, involving concentration degree of mining operations in the pit, have made it possible to determine that the scheme with lower unloading in the dump truck, located in the centre of the working bench width and the position of the dragline at a distance of $0.5 \mathrm{~A}$ from the bench crest is the most effective for the conditions of Motronivskyi MPP.

Acknowledgement. The research was conducted at the Department of Surface Mining at the National Mining University within the projects "Development of rational subsoil use to ensure stable operation of techno- and ecosystem mining areas and environment" (State registration No. 0113U000404) and "Development of environmentally friendly mining and mining reclamation technologies for efficient use of post-mining territories" (State registration No. 0116U004621).

\section{References.}

1. Sobko, B., Haidin, A., Lozhnikov, O., \& Jarosz, J. (2019). Method for calculating the groundwater inflow into pit when mining the placer deposits by dredger. E3S Web of Conferences, 123, 01025. EDP Sciences. https://doi.org/10.1051/e3sconf/201912301025.

2. Sobko, B., Drebenstedt, C., \& Lozhnikov, O. (2017). Selection of environmentally safe open-pit technology for mining water-bearing deposits. Mining of Mineral Deposits, 11(3), 70-75. https://doi. org $/ 10.15407 /$ mining 11.03 .070 .

3. Gorova, A., Pavlychenko, A., Kulyna, S., \& Shkremetko, O. (2013). The investigation of coal mines influence on ecological state of surface water bodies. Mining of Mineral Deposits, 303-305. https://doi. org/10.1201/b16354-56.

4. Anisimov, O., Symonenko, V., Cherniaiev, O., \& Shustov, O. (2018). Formation of safety conditions for development of deposits by open mining. E3S Web of Conferences, 60, 00016. EDP Sciences.

5. Semenenko, Y., Demchenko, T., \& Pavlichenko, A. (2020). Calculation of the maximum velocity of gravity flow in the pond-clarifier with higher aquatic plants. E3S Web of Conferences, 168, 00061. EDP Sciences. https://doi.org/10.1051/e3sconf/202016800061.

6. Sobko, B., Lozhnikov, O., \& Drebenshtedt, C. (2020). Investigation of the influence of flooded bench hydraulic mining parameters on sludge pond formation in the pit residual space. E3S Web of Conferences, 168, 00037. EDP Sciences. https://doi.org/10.1051/e3sconf/202016800037.

7. Kolosov, D., Dolgov, O., Bilous, O., \& Kolosov, A. (2015). The stress-strain state of the belt in the operating changes of the burdening conveyor parameters. New Developments in Mining Engineering 2015: Theoretical and Practical Solutions of Mineral Resources Mining, 585-590.

8. Kuzmenko, S., Kaluzhnyi, Ye., Moldabayev, S., Shustov, O., Adamchuk, A., \& Toktarov, A. (2019). Optimization of position of the cyclical-and-continuous method complexes when cleaning-up the deep iron ore quarries. Mining of Mineral Deposits, 13(3), 104-112. https://doi.org/10.33271/mining13.03.104.

9. Sobko, B. Yu., Lotous, V. V., Maievskyi, A. M., \& Drabakha, A. V. (2011). Determining the efficiency of dragline excavators operating in combination with heavy-duty dump trucks. Naukovyi Visnyk Natsionalnoho Hirnychoho Univesytetu, (5), 31-36.

10. Sobko, B. Yu., \& Lozhnikov, O. V. (2019). Determination of flooded placer deposits development technology efficiency during the ores and rocks separation at the floating concentration plant. Modern resource-saving technologies of mining production, 23, 75-84. 
11. Kolesnyk, V., Pavlychenko, A., Borysovska, O., Buchavyi, Y., \& Kulikova, D. (2020). Justification of the method of dust emissions localization on mobile crushing and sorting complexes of quarries with the use of air-and-water ejectors. E3S Web of Conferences, 168, 00029. EDP Sciences. https://doi.org/10.1051/e3sconf/202016800029.

12. Azarian, V., Lutsenko, S., Zhukov, S., Skachkov, A., Zaiarskyi, R., \& Titov, D. (2019). Applied scientific and systemic problems of the related ore-dressing plants interaction in the event of decommissioning the massif that separates their quarries. Mining of Mineral Deposits, 14, 1-10. https://doi.org/10.33271/mining14.01.001.

13. Dychkovskyi, R., Shavarskyi, Ia., Saik, P., Lozynskyi, V., Falshtynskyi, V., \& Cabana Edgar (2020). Research into stress-strain state of the rock mass condition in the process of the operation of double-unit longwalls. Mining of Mineral Deposits, 14, 85-94. https:// doi.org/10.33271/mining14.02.085.

14. Dychkovskyi, R., Tabachenko, M., Zhadiaieva, K., \& Cabana, E. (2019). Some aspects of modern vision for geoenergy usage. E3S Web of Conferences, 123, 01010. https://doi.org/10.1051/e3sconf/201912301010.

15. Tabachenko, M. (2016). Features of setting up a complex, combined and zero-waste gasifier plant. Mining of Mineral Deposits, 10(3), 37-45. https://doi.org/10.15407/mining10.03.037.

16. Dryzhenko, A., Shustov, A., \& Moldabayev, S. (2017). Justification of parameters of building inclined trenches using belt conveyors. International Multidisciplinary Scientific GeoConference: SGEM, 17(1.3), 471-478. https://doi.org/10.5593/sgem2017/13.

17. Sobolevskyi, R., Korobiichuk, V., Levytskyi, V., Pidvysotskyi, V., Kamskykh, O., \& Kovalevych, L. (2020). Optimization of the process of efficiency management of the primary kaolin excavation on the curved face of the conditioned area. Rudarsko-geološko-naftnizbornik, 35, 123-137. https://doi.org/10.17794/rgn.2020.1.10.

18. Litvinov, Yu., Terekhov, Ye., \& Fenenko, V. (2019). Improvement of open field development technology as a factor in the formation of quality and market value of reclaimed land. E3S Web of Conferences, 123, 01045. https://doi.org/10.1051/e3sconf/201912301045

19. Zhang, W., Cai, Q., \& Chen, S. (2013). Optimization of transport passage with dragline system in thick overburden open pit mine. International Journal of Mining Science and Technology, 23(6), 901-906. https://doi.org/10.1016/j.ijmst.2013.11.004.

20. Kolesnyk, V., Pavlychenko, A., Borysovska, O., Buchavyi, Yu., \& Kulikova, D. (2020). Justification of the method of dust emissions localization on mobile crushing and sorting complexes of quarries with the use of air-and-water ejectors. E3S Web of Conferences, 168, 00029. https://doi.org/10.1051/e3sconf/202016800029.

21. Prokopenko, V.I., Pilov, P.I., Cherep, A. Y., \& Pilova, D. P. (2020). Managing mining enterprise productivity by open pit reconstruction. Eurasian Mining, 2020(1), 42-46. https://doi.org/10.17580/ em.2020.01.08.

22. Simonenko, V., Hrytsenko, L., \& Cherniaiev, O. (2016). Organization of non-metallic deposits development by steep excavation layers. Mining of Mineral Deposits, 10, 68-73. https://doi.org/10.15407/ mining 10.04.068.

\section{Обгрунтування раціональної схеми навантаження автосамоскидів драглайнами при розробці кар'єру Мотронівського ГЗК}

\author{
Б. Ю. Собко, О. В. Ложніков, М. О. Чебанов, \\ B. A. Кардаш
}

Національний технічний університет «Дніпровська політехніка», м. Дніпро, Україна, e-mail: sobko.boris.nmu@ gmail.com

Мета. Обгрунтувати раціональну технологічну схему роботи екскаваторів драглайнів у комплексі з автосамоскидами, ураховуючи коефіцієнт концентрації гірничих робіт у кар'єрі.

Методика. Включала математичне та графічне моделювання при встановленні коефіцієнта концентрації гірничих робіт у кар'єрі й техніко-економічний аналіз для вибору раціональної технологічної схеми роботи екскаваторів драглайнів.

Результати. Розроблені рекомендації із вибору раціональних схем роботи екскаваторів драглайнів при навантаженні автосамоскидів для Мотронівсько-Аннівського кар'єру, з урахуванням показника ступеня концентрацій гірничих робіт у кар'єрі. Встановлено, що для даних умов найбільш ефективною є схема роботи драглайна 3 нижнім розвантаженням в автосамоскид, що розташовується посередині ширини заходки, та розташуванням драглайну на відстані 0,5А від верхньої бровки уступу. Запропонована технологічна схема розробки Мотронівсько-Аннівського кар'єру.

Наукова новизна. Встановлена залежність показника концентрації гірничих робіт у кар'єрі від параметрів елементів системи розробки за різними технологічними схемами, що дозволяє провести оцінку собівартості розробки порід розкриву при застосуванні екскаваторів драглайнів із безпосереднім розвантаженням до автосамоскидів.

Практична значимість. Розроблені технологічні схеми роботи екскаватора драглайна в комплексі з автосамоскидами, використання яких дозволяє знизити собівартість розкривних робіт. Застосування на практиці запропонованих рішень дозволяє зменшити витрати на розкрив на 79,65 млн грн/рік, при річному об'ємі розкривних порід $Q_{\text {rozkryvu }}=13,5$ млн м³ 3 рік.

Ключові слова: драглайн, автосамоскид, продуктивність екскаватора, коефіцієнт концентрації гірничих робіт, собівартість розкриву

Recommended for publication by L.N. Shirin, Doctor of Technical Science. The manuscript was submitted 20.10.20. 